\title{
(2) OPEN ACCESS \\ Tobacco industry tactics to circumvent and undermine the menthol cigarette ban in the UK
}

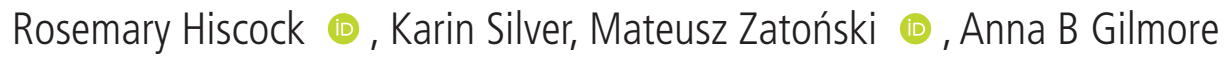

Tobacco Control Research Group, Department for Health, University of Bath, Bath, UK

\section{Correspondence to} Dr Rosemary Hiscock, Tobacco Control Research Group, Department for Health, University of Bath, Bath BA2 7AY, UK; R.Hiscock@bath.ac.uk

Received 14 March 2020 Revised 28 April 2020

Accepted 6 May 2020 Published Online First 17 May 2020

Check for updates

(C) Author(s) (or their employer(s)) 2020. Re-use permitted under CC BY-NC. No commercial re-use. See rights and permissions. Published by BMJ.

To cite: Hiscock R, Silver $\mathrm{K}$, Zatoński M, et al. Tob Control 2020;29:e138-e142.

\section{INTRODUCTION}

Menthol, a type of alcohol (molecular formula $\mathrm{C}_{10} \mathrm{H}_{20} \mathrm{O}$ ), can be obtained from mint plants or manufactured. ${ }^{1}{ }^{2}$ In addition to flavouring, it has local anaesthetic properties that can conceal the negative sensations of smoking, due to desensitising receptors. ${ }^{13}$ Menthol cigarettes increase overall smoke intake, but mask early respiratory disease symptoms, reducing the chance of quitting. ${ }^{4-6}$ Smoking menthol cigarettes also may raise nicotine intake, promoting nicotine dependence and the establishment of smoking in youth. ${ }^{45-9}$ Thus, banning menthol should reduce smoking prevalence. ${ }^{4}$ Furthermore, menthol cigarettes are likely to contribute to health inequalities as sociodemographic groups more likely to be of low income (low education, women, African-Americans and young people) are more likely to smoke menthol. ${ }^{10-13}$

A process for flavouring tobacco with menthol was first patented in the USA in the $1920 \mathrm{~s},{ }^{14}$ but mass distribution and marketing started in the 1960 s when a version with a filter was developed. ${ }^{8}{ }^{15} \mathrm{~A}$ more recent innovation for adding flavour is by the addition of a capsule, or 'crushball', a small plastic capsule in the filter activated by crushing ${ }^{16}$ (figure 1). These first appeared on the market in Japan in 2007 and are popular among young people due to the flavour and interactivity. ${ }^{16}{ }^{17}$ In the UK the only cigarettes available with capsules are menthol-flavoured. ${ }^{18}$

\section{THE EU MENTHOL BAN}

A ban on the sale of cigarettes with a characterising flavour, including menthol, was part of the revised European Tobacco Products Directive (EUTPD) (2014), which has been written into UK law and came into force in May 2016. ${ }^{19}$ To allow manufacturers and retailers a transitional period to prepare for the ban, implementation of the ban on flavours was delayed until May 2020, for flavours representing at least $3 \%$ of a product category European Union (EU)-wide, such as menthol. ${ }^{19} 20$

The legislation applies to cigarettes and rollyour-own (RYO) tobacco, with cigars, cigarillos and pipe tobacco exempt. Menthol accessories, which are not sold within the same packaging as tobacco or cigarettes, are also excluded. ${ }^{21}{ }^{22}$ Unlike the EU, Canada has now banned menthol as an ingredient $\mathrm{t}^{23}$; elsewhere, cigarettes not labelled as menthol can contain menthol at subliminal levels to reduce the negative sensations of smoking. ${ }^{24-26}$

Leaked Philip Morris International (PMI) documents reveal that it opposes flavour bans, ${ }^{27}$ and our monitoring of industry activity indicates that tobacco companies have been exploiting loopholes in the menthol ban and related legislation in the UK, particularly in the months leading up to the ban. The purpose of the paper is, therefore, to expose these gaps and loopholes that other jurisdictions may need to close when developing similar legislation.

\section{Tobacco industry use of the delay to menthol ban implementation}

Data on market share of menthol and capsule cigarettes show that menthol/capsule median market share across EU countries (excluding UK) declined from 2015, the year after the TPD was announced (figure 2). In the UK, however, market share increased, via growth in capsule cigarettes, from $14 \%$ in 2014 to $21 \%$ in 2018, approximately twice and four times the EU median, respectively. Growth was steeper in the UK than in other European countries without the ban (figure 2). Therefore, it does not appear that the UK tobacco industry has been using the grace period to prepare for the menthol ban, but has instead used it to prolong and increase menthol sales. ${ }^{28} 29$

Sixteen per cent of menthol smokers say they intend to quit after the menthol ban is implemented. ${ }^{30}$ With sales of six billion menthol cigarette sticks in 2018, this could reduce tobacco industry sales by around onebillion sticks (3\% of the total cigarette market) in the $\mathrm{UK},{ }^{31}$ so it is not surprising tobacco companies have looked to circumvent the ban.

The derogation delayed implementation until the COVID-19 pandemic. A trade journal reported industry representatives taking advantage of retail closures to request a further deferment ${ }^{32}$ despite cigarette sales, and thus old stock turnover, spiking rather than declining. ${ }^{33}$

\section{Product innovation to circumvent and undermine regulation}

As tobacco accessories sold separately are excluded from the legislation, companies have been introducing various menthol-flavoured accessories. Imperial launched menthol ${ }^{34}$ and capsule ${ }^{35}$ RYO filter tips in mid-2017 and January 2019, respectively. Independent RYO and make your own accessories specialist, the Republic Group, ${ }^{36}$ also introduced a new menthol filter via its Swan brand. ${ }^{37}$ These products could encourage menthol cigarette smokers to switch to RYO rather than quit. Imperial also announced the launch of 'menthol chill' and 'fresh mint' 'Flavour Infusion Cards' in January 2020, designed to provide a menthol 


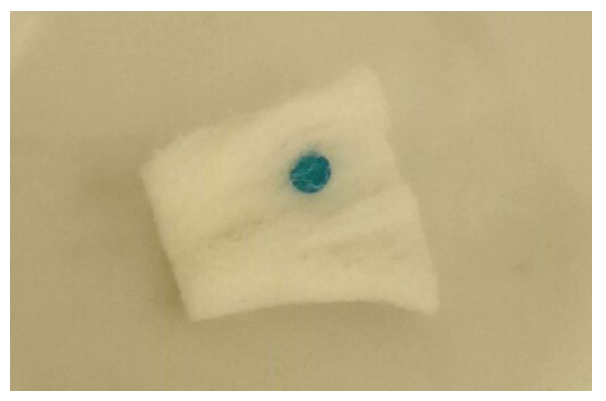

Figure 1 Menthol capsule located inside a filter.

flavour if inserted into factory-made cigarettes or packs of RYO tobacco. $^{38} 39$

Unlike tobacco products, in England and Wales accessories such as these can be displayed at point of sale (including branding), whereas in Scotland they also need to be hidden from view. ${ }^{40} 41$ Imperial Tobacco has recommended that retailers use point-of-sale displays to promote the flavour infusion cards. ${ }^{38}$

About 5 months before the ban, Japan Tobacco International (JTI) launched 10-pack cigarillos with menthol capsules. These closely resemble cigarettes and are placed under its Sterling cigarette brand, and have been promoted to retailers as a way to circumvent the menthol ban. ${ }^{42}$ The Scandinavian Tobacco Group, a specialist producer of cigars, is also launching a cigarillo with a capsule in the filter called Signature Dual. ${ }^{37}{ }^{39}$ Euromonitor data suggest a growth in sales of cigarillos since the EUTPD and associated UK legislation ${ }^{43}$ were enacted in 2016, reversing a downward trend, unlike the cigar market which continues to fall (figure 3).

PMI, which has only a small market share in the UK, is exploiting the opportunity to promote IQOS as an alternative to menthol cigarettes, as its tobacco HEETs sticks are not covered by the ban. ${ }^{37} 39$

Source: Euromonitor February 2020 (Note that Euromonitor receives project funding from Philip Morris International (Gallagher, A. W., \& Gilmore, A. (2019). Euromonitor International now accepts tobacco industry funding: a win for PMI at the expense of research on the tobacco industry [Blog]. Tobacco Control(April 8th).)

UK: United Kingdom of Great Britain and Northern Ireland

EU: median of the following European Union countries: Italy, Greece, Spain, Estonia, Sweden, Slovenia, Lithuania, Romania, Croatia, Austria, Denmark, Portugal, Slovakia, Latvia, Ireland, Poland, Bulgaria, Netherlands, Hungary, Czech Republic, France, Finland, Belgium, Germany

Other WHO Europe: median of the following countries: Switzerland, Norway, Serbia, Bosnia and Herzegovina, North Macedonia; Azerbaijan, Uzbekistan, Georgia, Belarus, Russia, Ukraine, Kazakhstan, Israel and Turkey

Figure 2 Market share of menthol and capsule cigarettes, WHO Europe region. 


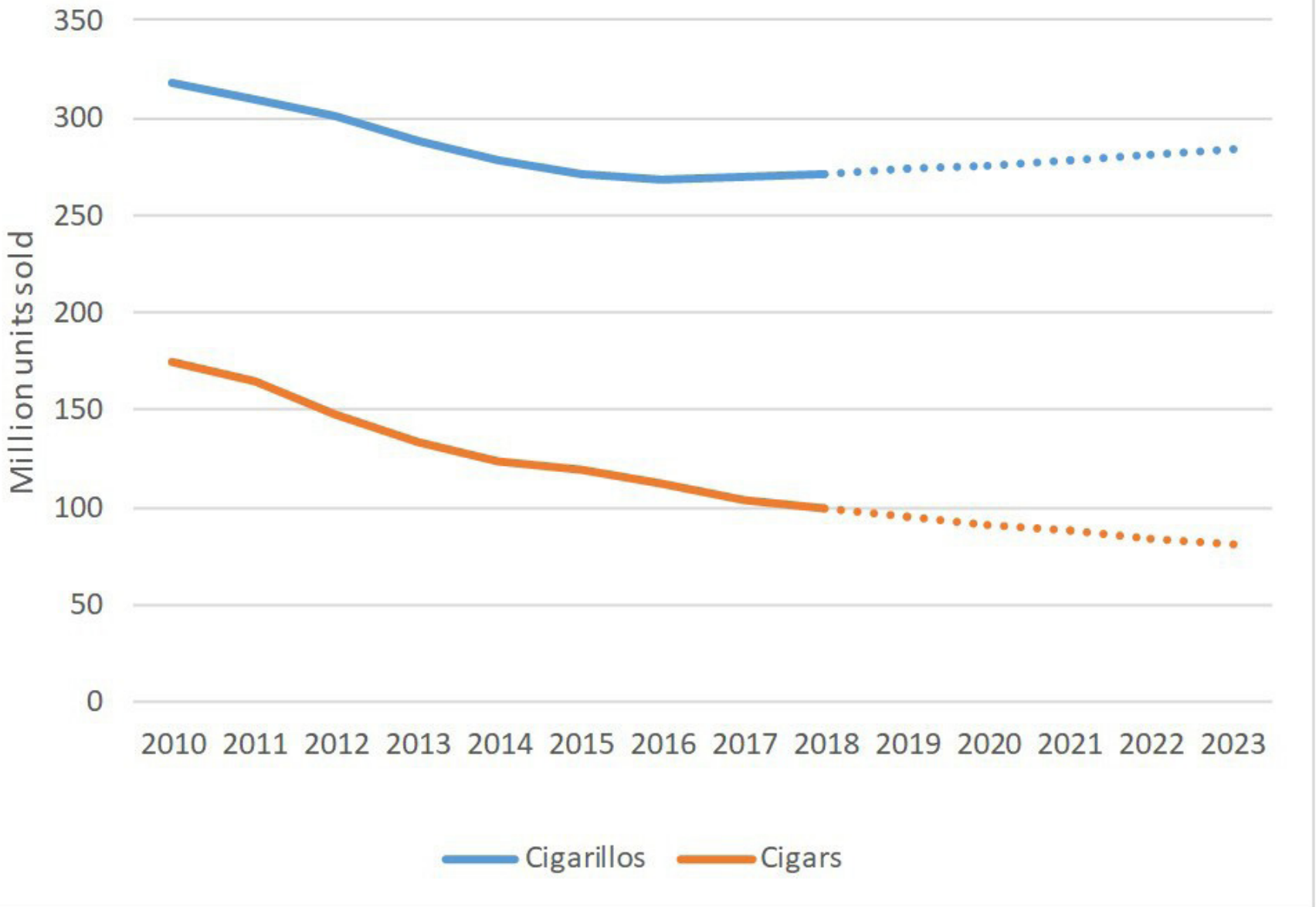

\section{Source: Euromonitor International downloaded January 2020, dotted lines represent forecast data}

\section{Figure 3 Expected UK growth in cigarillos and cigars.}

Given that the UK does not allow promotion ${ }^{44}$ or display ${ }^{41}$ of tobacco products, the tobacco industry has widely promoted these new and diverse products to retailers via the retail press. $^{21} 35373845$ They have also created dedicated websites for retailers and smokers. ${ }^{39}{ }^{46-49}$ Although ostensibly set up to provide information, these websites in effect promote nextgeneration products (NGPs). One encourages retailers to calculate their potential losses from reduced cigarette sales while reassuring them that other menthol products are available. ${ }^{48}$ Another presents three boxes with options to smokers-quit, heat and vape-and devotes more space and words to NGP options than quitting. ${ }^{47}$

\section{CONCLUSIONS}

The tobacco industry has introduced diverse new products to the UK that can get around the ban: menthol accessories sold separately from cigarette packs, and RYO pouches and cigarillos with a capsule. It has also used the ban to promote more profitable $^{50}$ heated tobacco products, which unlike quitting are not risk-free. ${ }^{51-54}$ Despite claims of a commitment to reducing harm, this provides yet further evidence that the tobacco industry will circumvent and undermine measures with genuine potential to reduce harm.

Cigarillos are likely to be particularly attractive to the tobacco industry because they are exempt from EU and UK standardised pack legislation (with the exception of large pictorial warnings), are subject to lower taxes, and their definition is such that they can be sold looking similar to conventional cigarettes except for a brown leaf rather than white stick covering. ${ }^{42}$ Thus, the tobacco industry may use cigarillos to reintroduce cigarette branding and cheap products which had been removed by standardised packaging. ${ }^{2155}$

The EU/UK menthol ban was associated with preceding falls in menthol sales in the EU, but in the UK sales grew up to implementation. This suggests not only that a long implementation period was not needed but that it was misused: menthol sales, which may be particularly harmful, ${ }^{4}$ were driven up in the UK. The yearlong standardised packaging implementation period in the UK was similarly exploited by the tobacco industry. ${ }^{2155}$

As other jurisdictions seek to implement flavour bans, standardised packaging and display bans, we suggest they aim to eliminate the weaknesses the industry exploited in the UK legislation. This could be achieved by including all tobacco products and accessories, encompassing all pack types and flavours. Presenting legislation this way, rather than specifying each product included, also helps future-proof it. Further, as in Canada, banning menthol as an ingredient has the benefit of ensuing the industry cannot continue to include menthol at below observable levels. There should be no derogations or phase-ins, in order to maximise impact and curtail sales quickly. 
Correction notice The paper has been updated since first publish to amend references.

Twitter Mateusz Zatoński @ZatonskiMateusz and Anna B Gilmore @BathTR

Contributors All authors contributed to drafting the paper and approved the final version. RH collated and analysed the Euromonitor data and took the photo (figure 1). RH and KS collated and analysed the industry documents. KS wrote the initial notes for drafting the manuscript, and RH was responsible for much of the redrafting of the manuscript. MZ contributed particularly to the academic literature review. ABG is the head of the research group, spotted the cigarillos on sale, conceived the idea for the paper and provided thoughts for policy responses.

Funding This project was supported by Bloomberg Philanthropies Stopping Tobacco Organizations and Products project funding (www.bloomberg.org) and Cancer Research UK Harnessing Big Data Alongside Investigative Methods: Investigating Tobacco Industry Conduct in an Era of Political Uncertainty (https://www. cancerresearchuk.org/).

\section{Competing interests None declared.}

Patient consent for publication Not required.

Provenance and peer review Not commissioned; externally peer reviewed.

Open access This is an open access article distributed in accordance with the Creative Commons Attribution Non Commercial (CC BY-NC 4.0) license, which permits others to distribute, remix, adapt, build upon this work non-commercially, and license their derivative works on different terms, provided the original work is properly cited, appropriate credit is given, any changes made indicated, and the use is non-commercial. See: http://creativecommons.org/licenses/by-nc/4.0/.

\section{ORCID iDs}

Rosemary Hiscock http://orcid.org/0000-0001-9741-9083

Mateusz Zatoński http://orcid.org/0000-0001-7254-569X

\section{REFERENCES}

1 US National Library of Medicine National Center for Biotechnology Information. PubChem compound summary: menthol, 2020. Available: https://pubchem.ncbi.nlm. nih.gov/compound/Menthol [Accessed 6th Feb 2020].

2 WHO Study Group on Tobacco Product Regulation. Advisory note: banning menthol in tobacco products, 2016. https://www.who.int/tobacco/publications/prod_regulation/ menthol-advisory-note/en/

3 FDA. Menthol cigarettes and public health: review of the scientific evidence and recommendations, 2011. Available: https://wayback.archive-it.org/7993/ 20170405201731/https:/www.fda.gov/downloads/AdvisoryCommittees/Committe esMeetingMaterials/TobaccoProductsScientificAdvisoryCommittee/UCM269697.pdf [Accessed 12th Feb 2020].

4 Villanti AC, Collins LK, Niaura RS, et al. Menthol cigarettes and the public health standard: a systematic review. BMC Public Health 2017;17:983.

5 Danish Cancer Society. Tobacco additives - a study of the available literature, 2008. Available: http://tobacco.cleartheair.org.hk/wp-content/uploads/2008/06/tobaccoadditives.pdf [Accessed 13th Feb 2020].

6 Ahijevych K, Weed H, Clarke J. Levels of cigarette availability and exposure in black and white women and efficient smokers. Pharmacol Biochem Behav 2004;77:685-93.

7 Henningfield JE, Benowitz NL, Ahijevych K, et al. Does menthol enhance the addictiveness of cigarettes? An agenda for research. Nicotine Tob Res 2003:5:9-11.

8 Herbeć A, Zatoński M, Zatoński WA, et al. Dependence, plans to quit, quitting selfefficacy and past cessation behaviours among menthol and other flavoured cigarette users in Europe: the EUREST-PLUS ITC Europe surveys. Tob Induced Dis 2018;16.

9 Curtin GM, Sulsky SI, Van Landingham C, et al. Primary measures of dependence among menthol compared to non-menthol cigarette smokers in the United States. Regul Toxicol Pharmacol 2014;69:451-66.

10 FDA. Preliminary scientific evaluation of the possible public health effects of mentho versus nonmenthol cigarettes, 2013. Available: https://www.fda.gov/media/86497/ download

11 WHO Study Group on Tobacco Product Regulation. Report on the scientific basis of tobacco product regulation. World Health Organization, 2009.

12 Hersey JC, Ng SW, Nonnemaker JM, et al. Are menthol cigarettes a starter product for youth? Nicotine Tob Res 2006;8:403-13.

13 Kingsbury JH, Hassan A. Community-led action to reduce menthol cigarette use in the African American community. Health Promot Pract 2020;21:72S-81.

14 Hughes L. Inventor process of treating cigarette tobacco. United States, 1925.

15 Sutton CD, Robinson RG. The marketing of menthol cigarettes in the United States: populations, messages, and channels. Nicotine Tob Res 2004;6:83-91.

16 Thrasher JF, Abad-Vivero EN, Moodie C, et al. Cigarette brands with flavour capsules in the filter: trends in use and brand perceptions among smokers in the USA, Mexico and Australia, 2012-2014. Tob Control 2016;25:275-83.

17 Moodie C, MacKintosh AM, Thrasher JF, et al. Use of cigarettes with Flavor-Changing capsules among smokers in the United Kingdom: an online survey. Nicotine Tob Res 2019;21:1547-55
18 Department of Health, Department of Health and Social Services Northern Ireland, The Scottish Office Department of Health, Welsh Office. Report of the Scientific Committee on Tobacco and Health: Annex K: The Stationary Office, 1998. Available: https://assets. publishing.service.gov.uk/government/uploads/system/uploads/attachment_data/file/ 259796/report.pdf [Accessed 2nd Mar 2020].

19 Directive 2014/40/EU of the European Parliament and of the Council of 3 April 2014. Available: https://eur-lex.europa.eu/legal-content/EN/TXT/?uri=OJ\%3AJOL_2014_ 127_R_0001

20 European Commission. Memo: Questions \& Answers: New rules for tobacco products Brussels, 2014. Available: http://europa.eu/rapid/press-release_MEMO-14-134_en. htm [Accessed 3rd Mar 2014].

21 Evans-Reeves KA, Hiscock R, Lauber K, et al. Prospective longitudinal study of tobacco company adaptation to standardised packaging in the UK: identifying circumventions and closing loopholes. BMJ Open 2019;9:e028506.

22 Walker G. Updated ACS advice offers key clarification on menthol tobacco ban. Convenience Store [Internet], 2020. Available: https://www.conveniencestore.co.uk/ news/updated-acs-advice-offers-key-clarification-on-menthol-tobacco-ban/601921. article [Accessed 14th Feb 2020].

23 Canadian Federal Government. Tobacco and vaping products act, SC 1997, C 13 : Canadian legal information Institute, 2019. Available: https://www.canlii.org/en/ca/ laws/stat/sc-1997-c-13/latest/sc-1997-c-13.html [Accessed 9th Nov 2019].

24 Perfetti T. Applied research and development. 1984 20th December. In: Menthol and the design of mentholated cigarette course [Internet]. RJ Reynolds Master Settlement Agreement. Available: https://www.industrydocuments.ucsf.edu/docs/ slkn0095

25 Bexon R. R\&D/Marketing Conference. Canadian Tobacco Industry Collection [Internet] 1984. Available: https://www.industrydocuments.ucsf.edu/docs/mzhb0223 [Accessed 24th Apr 2020].

26 Ai J, Taylor KM, Lisko JG, et al. Menthol levels in cigarettes from eight manufacturers. Tob Control 2018:27:335-6.

27 Philip Morris International. Corporate affairs approach and issues, 2014. Available: https://web.archive.org/web/20200304140037/https://www.documentcloud.org/ documents/3892762-2014-Corporate-Affairs-Approach-and-Issues.html [Accessed 4th Mar 2020].

28 Dodds W. Retailers call on suppliers to buy back tobacco ahead of menthol ban. betterRetailing.com [Internet], 2019. Available: https://www.betterretailing.com/ products/tobacco/retailers-call-on-suppliers-buy-back-tobacco-menthol-ban/ [Accessed 14th Feb 2020].

29 BetterRetailing com. Exclusive: retailers warned to clear non-track-and-trace stock, 2020. Available: https://www.betterretailing.com/products/tobacco/retailers-warnedclear-non-track-and-trace-stock/ [Accessed 12th Feb 2020].

30 Zatoński M, Herbeć A, Zatoński W, et al. Characterising smokers of menthol and flavoured cigarettes, their attitudes towards tobacco regulation, and the anticipated impact of the Tobacco Products Directive on their smoking and quitting behaviours: the EUREST-PLUS ITC Europe surveys. Tob Induc Dis 2018;16:A4-A.

31 Euromonitor Passport. Market sizes: cigarettes retail volume, 2018. Available: https:// go.euromonitor.com/passport.html [Accessed 4th Mar 2020].

32 Tobacco Reporter. EU menthol ban: industry asks for more time, 2020. Available: https://tobaccoreporter.com/2020/04/21/eu-menthol-ban-industry-asks-for-moretime/ [Accessed 27th Mar 2020].

33 Nilsson P, Middlehurst C, Evans J. Smokers stock up on tobacco and nicotine products. Financial Times [Internet], 2020. Available: https://www.ft.com/content/362d7d516561-493b-a29b-72784157cca7 [Accessed 4th Apr 2020].

34 Cronin E. Rizla launches new Natura paper and tips range. talkingretail.com [Internet], 2017. Available: https://www.talkingretail.com/products-news/tobacco/rizla-launchesnew-natura-paper-tips-range-03-08-2017/ [Accessed 14th Feb 2020].

35 Cronin E. Imperial tobacco unveils crushball filter tip. talkingretail.com [Internet], 2018. Available: https://www.talkingretail.com/products-news/tobacco/imperialtobacco-unveils-crushball-filter-tip-11-12-2018/ [Accessed 14th Feb 2020].

36 Republic Technologies UK. About us. Available: https://web.archive.org/web/ 20200310100522/https:/www.republictechnologies.co.uk/about.html [Accessed 10th Mar 2020]

37 Hegarty R. Focus on tobacco: Smooth criminal - the smooth taste of menthol cigarettes will soon be illegal, as flavoured variants are banned How is big tobacco fighting back? The Grocer 2020:49-54.

38 Cronin E. Imperial Tobacco adds menthol accessories to portfolio. talkingretail.com [Internet], 2019. Available: https://www.talkingretail.com/products-news/tobacco/ imperial-tobacco-adds-menthol-accessories-portfolio-16-12-2019/ [Accessed 14th Feb 2020]

39 Tobacco Tactics. Menthol cigarettes: tobacco industry interests and interference, 2020 https://tobaccotactics.org/wiki/menthol-cigarettes-tobacco-industry-interests-andinterference/

40 Convenience Store. Dealing in a dark market, 2015. Available: https://www. conveniencestore.co.uk/products-in-depth/dealing-in-a-dark-market/515145.article [Accessed 14th Feb 2020].

41 House of Commons Library. Prohibition of tobacco displays. Briefing Paper [Internet], 2020. Available: http://researchbriefings.files.parliament.uk/documents/SN05537/ SN05537.pdf [Accessed 13th Mar 2020]. 
42 Branston J, Hiscock R, Silver K, et al. Cigarette like Cigarillo introduced to bypass taxation and product regulation in the UK. Tob Control. In Press.

43 UK Parliament. The standardised packaging of tobacco products regulations, 2015. Available: http://www.legislation.gov.uk/uksi/2015/829/2019-05-20 [Accessed 12th Sep 2019].

44 ASH. Advertising promotion and sponsorship, 2016. Available: https://ash.org.uk/ information-and-resources/law-guide/advertising-promotion-sponsorship/ [Accessed 13th Mar 2020].

45 Dillon C. Preparing for the menthol ban with Imperial Tobacco. BetterRetailing. com [Internet], 2020. Available: https://www.betterretailing.com/products/tobacco/ preparing-for-the-menthol-ban-imperial-tobacco/

46 JTI. JTI advance: menthol ban, 2020. Available: https://www.jtiadvance.co.uk/ MentholBan2020 [Accessed 2nd Mar 2020].

47 Philip Morris Limited. Menthol-ban: a moment of change. Available: https://www. menthol-ban.co.uk/?gclid=CjwKCAiA-VLyBRBWEiwAzOKGVK8KDIIHL9xtJwh-bYV-8jTK 9si6gQmcpxMDKJXjX8tTRloGwKE_YhoCv1UQAvD_BwE [Accessed 2nd Mar 2020].

48 Philip Morris Limited. IQOS, 2020. Available: https://web.archive.org/web/ 20200221161451/https://menthol-ban-retail.co.uk/ [Accessed 19th Feb 2020].
49 JTI. JTI advance: menthol ban 2020: what's going to happen. Available: https://www. jtiadvance.co.uk/mentholban2020/customer-info [Accessed 13th Mar 2020].

50 Stopping Tobacco Organisations and Products. Addiction at any cost: Philip Morris international uncovered: STOP report, 2020. Available: https://exposetobacco.org/ wp-content/uploads/STOP_Report_Addiction-At-Any-Cost.pdf [Accessed 21st Feb 2020].

51 Jankowski M, Brożek GM, Lawson J, et al. New ideas, old problems? Heated tobacco products - a systematic review. Int I Occup Med Environ Health 2019;32:595-634.

52 Pisinger C, Mackay J. New tobacco products do not protect public health. Ann Am Thorac Soc 2019;16:1363-5.

53 Simonavicius E, McNeill A, Shahab L, et al. Heat-not-burn tobacco products: a systematic literature review. Tob Control 2019;28:tobaccocontrol-2018-054419.

54 Tobacco Tactics. Next generation products, 2020. Available: https://tobaccotactics.org/ wiki/next-generation-products

55 Hiscock R, Augustin NH, Branston JR, et al. Standardised packaging, minimum excise tax, and RYO focussed Tax rise implications for UK tobacco pricing. PLoS One 2020;15:e0228069. 